JEL: M41, O13, Q10

\author{
Valerii Zhuk', Iryna Zamula $^{2}$, Dmytro Liudvenko ${ }^{1}$, Yevheniya Popko ${ }^{1}$ \\ ${ }^{l}$ National Scientific Center «Institute of Agrarian Economics» \\ ${ }^{2}$ Zhytomyr Polytechnic State University \\ Ukraine
}

\title{
DEVELOPMENT OF NON-FINANCIAL REPORTING OF AGRICULTURAL ENTERPRISES OF UKRAINE
}

Purpose. The purpose of the study is to develop non-financial reporting of medium-sized agricultural enterprises of Ukraine through the definition of the main activities of the enterprise, which are subject to disclosure in non-financial reporting, to meet the information needs of internal and external stakeholders of such enterprises.

Methodology / approach. The research methods are based on dialectical and systematic approaches to assessing the current state of non-financial reporting of Ukrainian enterprises. Methods of analysis and synthesis are used to determine the main activities of agricultural enterprises, which are subject to disclosure in non-financial statements, based on requests from interested users. To obtain data on information requests of internal stakeholders of the surveyed enterprises, continuous initial observation was applied, and external sample holders were subjected to continuous sample observation. Internal (in particular, the population units are employees and owners) and external (in particular, the population units are contractors, consumers, creditors, investors, government agencies, NGOs) stakeholders are selected as the object of observation.

Results. According to the results of the study, in the formation of non-financial reporting agricultural enterprises of Ukraine should pay special attention to areas of activity that are of greatest interest to stakeholders: development and improvement of working conditions, investment in regional development, respect for human rights, implementation of CSR programs in the supply chain. The main activities of the company, which are subject to disclosure in non-financial reporting, provide an opportunity to meet the information needs of internal and external stakeholders.

Originality / scientific novelty. Failure to meet information needs of both internal and external stakeholders of agricultural enterprises has necessitated the improvement of organizational and methodological approaches to the formation of non-financial reporting of agricultural enterprises by identifying the main activities of the enterprise to be disclosed in nonfinancial reporting. The use of these areas creates an opportunity for stakeholders to obtain data that provide integrated information on the activities of agricultural enterprises.

Practical value / implications. Disclosure of information in accordance with certain main activities of the enterprise will reduce the cost of users to obtain, process and systematize data, which will reduce inefficient use of resources in the preparation, substantiation, implementation and evaluation of economic decisions, as well as increase analytical capabilities for its use in the interest of stakeholders. The identified main areas of activity can be used as a basis for developing a long-term strategy for the formation of non-financial reporting of the agricultural enterprise, which will simplify the preparation of information for its full disclosure. This will increase the level of transparency of enterprises and will serve as a tool for building their positive reputation.

Key words: information needs, non-financial reporting, sustainable development reporting, corporate social responsibility, agricultural enterprises. 


\section{Agricultural and Resource Economics: International Scientific E-Journal}

http://are-journal.com

Introduction and review of literature. Much attention of the world community in the last decade is paid to the growth of the level and quality of life of the population. Since 2015, the Sustainable Development Agenda for the period up to 2030 has been launched [1], which provides for 17 global goals and 169 tasks to achieve them. The envisaged goals are complex and indivisible and are aimed at ensuring the achievement of economic, environmental and social provisions of the concept of sustainable development.

For many decades, anthropocentric ecological consciousness was formed, when man put himself and his needs above the needs of nature, which led to the current global environmental crisis [2;3]. Therefore, at this stage of development of society, the desire to form an ecological consciousness of the ecocentric type is proclaimed, when the needs of man and nature are mutually balanced.

The economic tradition of consumer, unbalanced attitude to natural resources, which has developed in Ukraine, is an obstacle to achieving the provisions of the concepts of sustainable development [4]. The main reasons observed in Ukraine today are: the prevalence of economic performance over environmental, significant consumption of resources and energy by enterprises of various sectors of the economy, as well as significant wear and tear of their fixed assets, low environmental awareness [5].

For a long time, Ukraine's economic development was accompanied by unbalanced exploitation of natural resources, low priority of environmental issues, which made it impossible to achieve sustainable development. One of the ways to improve the environmental situation in the country is to create an effective system of access to public information on environmental protection [6;7]. At the same time, the information should be of high quality and meet the requests of interested users regarding the composition, clarity, completeness, etc. of the published indicators [8; 9].

Today, information on the compliance of business entities with the requirements of the concept of sustainable development is disclosed by them in various reporting documents. Thus, almost $78 \%$ of companies in the world prepare non-financial reports, and $40 \%$ of companies in the world began to include non-financial indicators in annual reports [10, p. 9].

Such trends in the disclosure of information by enterprises have led to the formation of integrated reporting, which includes financial and non-financial indicators that reveal the economic and social aspects of the entity in the short, medium and long term.

The vast majority of reporting in the world, namely $80 \%$, which discloses nonfinancial indicators, is formed on the basis of the requirements of GRI standards [11]. Ukrainian enterprises are less active in applying GRI standards, but there is a positive trend (Fig. 1).

In Ukraine, the formation of reporting with non-financial indicators is just beginning to develop $[7 ; 13]$. Representation offices of foreign companies in Ukraine and the largest Ukrainian enterprises are most actively engaged in this issue. 
The study of issues of reporting on sustainable development and information support of users on the environmental aspects of the enterprise has received considerable attention from scientists around the world. Thus, the study of G. Atağan [14] assesses the interaction between integrated reporting and sustainability accounting in terms of theory. The study was conducted by reviewing the literature and analyzing the firms listed in the BIST Sustainability Index.

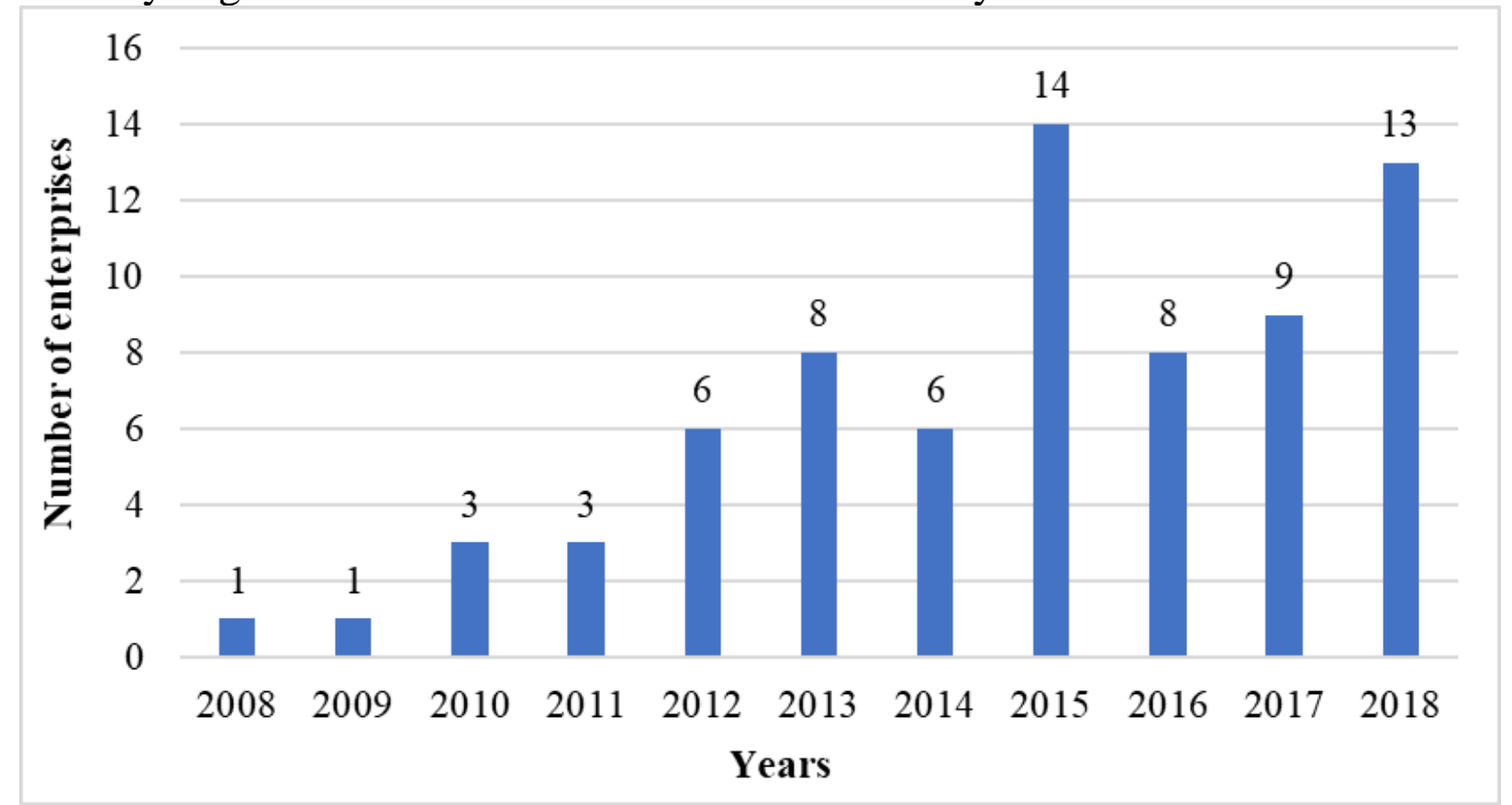

Fig. 1. Dynamics of the number of business entities of Ukraine that submit reports in accordance with GRI

Sourse: compiled in accordance with [12].

M. Bednarova, R. Klimko and E. Rievakhova [15] identify the factors influencing the disclosure of environmental indicators and environmental performance of the 100 best companies in the world. The analysis involved determining their compliance with the Global Reporting Initiative standards to obtain and maintain legitimacy with relevant stakeholders.

The research of E. Truant, L. Corazza and S. Domenico Scagnelli [16] aims to address issues related to the development of risk management tools for understanding the risks of sustainability in management and reporting practices.

The study by E. Dobre, G. Oana Stanila and L. Brad [17] aims to provide information on how Romanian listed companies report on environmental and social indicators and whether this affects financial performance.

R. Camodeca, A. Almici and U. Sagliaschi [18] investigated the value of disclosing information about the sustainability of corporate business through integrated reporting.

The research of E. Abad-Segura, F. Joaquín Cortés-García and L. J. BelmonteUreña [19] aims to determine the relevance of corporate social responsibility and its relationship to sustainable development, in order to identify trends and future directions of research. 


\section{Agricultural and Resource Economics: International Scientific E-Journal}

http://are-journal.com

G. Vitale, S. Cupertino, L. Rinaldi and A. Riccaboni [3] have deepened and sought empirical evidence of how accounting, control and reporting systems for sustainability management can be integrated through the equalization process.

B. Zyznarska-Dworczak's study [20] aims to promote the perception of changes and prospects for the development of management accounting in Central and Eastern Europe with in-depth consideration of corporate social responsibility, consideration of the role of accounting in a broader sense: social, ethical, environmental, cultural and historical contexts.

The study of L. Ukrainska, O. M. Kryukova, G. Yu. Korneeva [21] deals with the analysis of the ecological situation and determination of Ukraine's place in the main international ecological ratings and indices, coverage of the world experience of development of the system of ecological and economic accounts and ecologically adjusted macroeconomic indicators, substantiation of the need to take into account the ecological component of sustainable development in the calculation of national macroeconomic indicators of Ukraine.

Further research is needed to determine the main activities of the enterprise, which is subject to disclosure in non-financial statements at the request of internal and external stakeholders of such enterprises.

The purpose of the article is the development of non-financial reporting of medium-sized agricultural enterprises of Ukraine through the definition of the main activities of the enterprise, which are subject to disclosure in non-financial reporting, to meet the information needs of internal and external stakeholders of such enterprises.

To achieve this goal, the following tasks are provided: to study the state of nonfinancial reporting in Ukraine; based on the requests of stakeholders to determine the main activities of agricultural enterprises, which are subject to disclosure in their nonfinancial statements.

Results and discussion. Among 180 countries in the world, Ukraine ranks 60th in the ranking of the Environmental Performance Index (IEE 2020), which takes into account the main indicators of the country in terms of rational use and conservation of natural resources [22]. An IEE value of 0 characterizes the worst condition, $100-$ the best condition. To determine the IEE 24 indicators that characterize the state of natural resources and the impact of anthropogenic activity are used (Fig. 2).

In the current year, the IEE of Ukraine amounted to 49.5 points. The worst values were indicators that assess fish stocks (12.4 points) and the quality of available water resources (14.1 points). In addition, a number of indicators are rated less than 50 points, which is an unsatisfactory indicator.

The largest changes for the period 2010-2020 took place in the indicator "Agriculture", that had the absolute increase of 18.3, which is caused by the increase in the use of mineral fertilizers. Ukraine's agricultural sector plays a key role in promoting sustainable economic and social development. Ukraine's agricultural sector employs about 3 million people, and in 2017 produced about $10 \%$ of total GDP and $42 \%$ of total exports [23]. Therefore, a considerable attention should be 
given to its ecologization from the standpoint of various fields of science and practice.

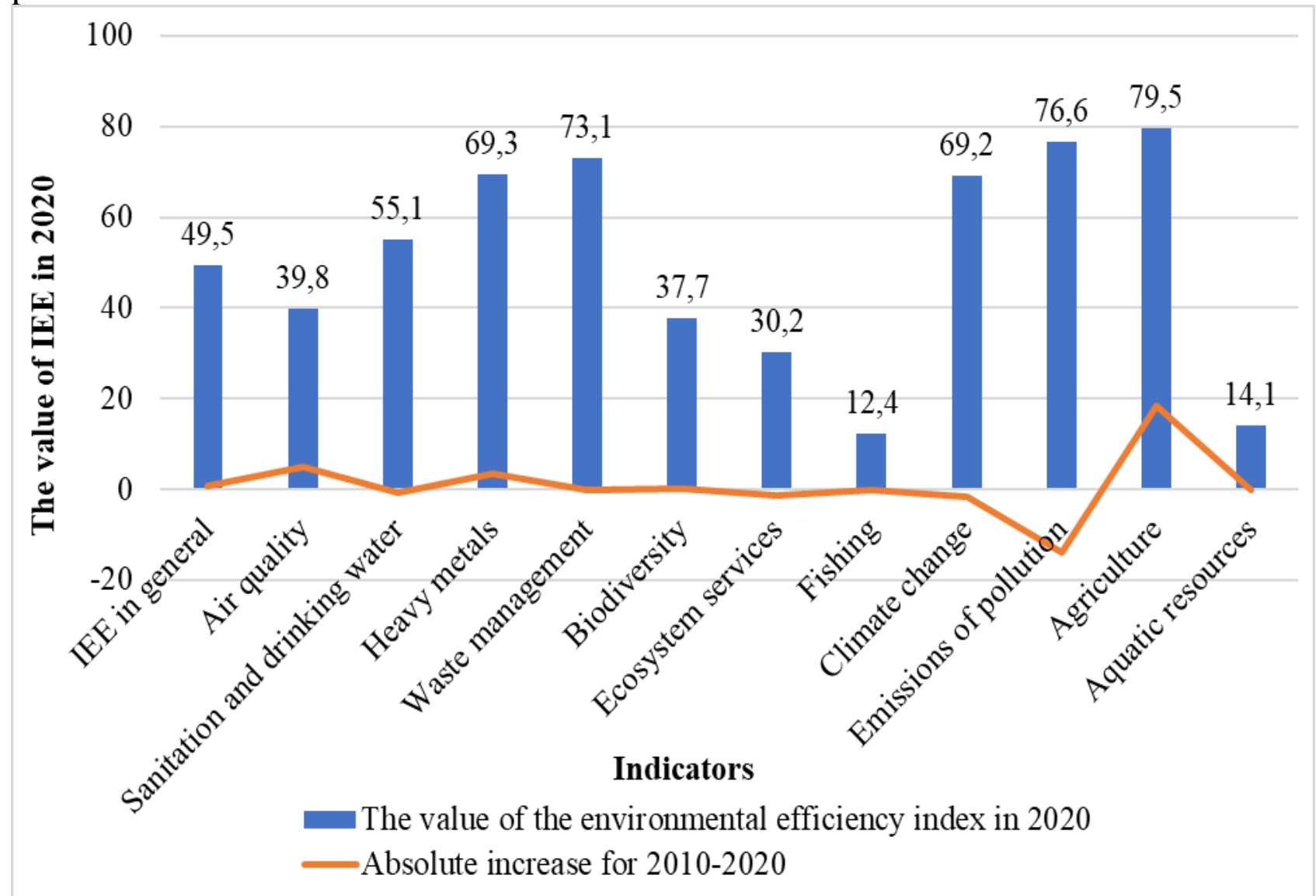

Fig. 2. The value of the index of environmental efficiency and indicators that form it, for 2020

Sourse: formed by authors based on [22].

Ukraine's ratification of the terms of the UN Global Compact has become a major reason for the development of non-financial reporting and the number of companies involved in this process is increasing. To date, a group of companies has been formed that are leaders in non-financial reporting and to some extent determine the directions of its development.

As of 2018, $83 \%$ of Ukrainian enterprises implement a policy of corporate social responsibility, $60 \%$ of which included concern for the environment in such responsibility [24, p. 12]. An interesting fact is that $37 \%$ of the surveyed enterprises have implemented a policy of corporate social responsibility for moral reasons, which characterizes the growing level of environmental awareness of business entities and, consequently, society as a whole (Fig. 3).

At the same time, enterprises pursuing corporate social responsibility policies pursued pragmatic goals, such as improving the company's reputation $(18 \%$ of respondents), increasing staff loyalty (16\%), simplifying innovation $(8 \%)$, and increasing sales $(7 \%)$. And only $5 \%$ of the surveyed enterprises stated that they implement a policy of corporate social responsibility at the request of local authorities and form reports on corporate social responsibility based on their requests. 


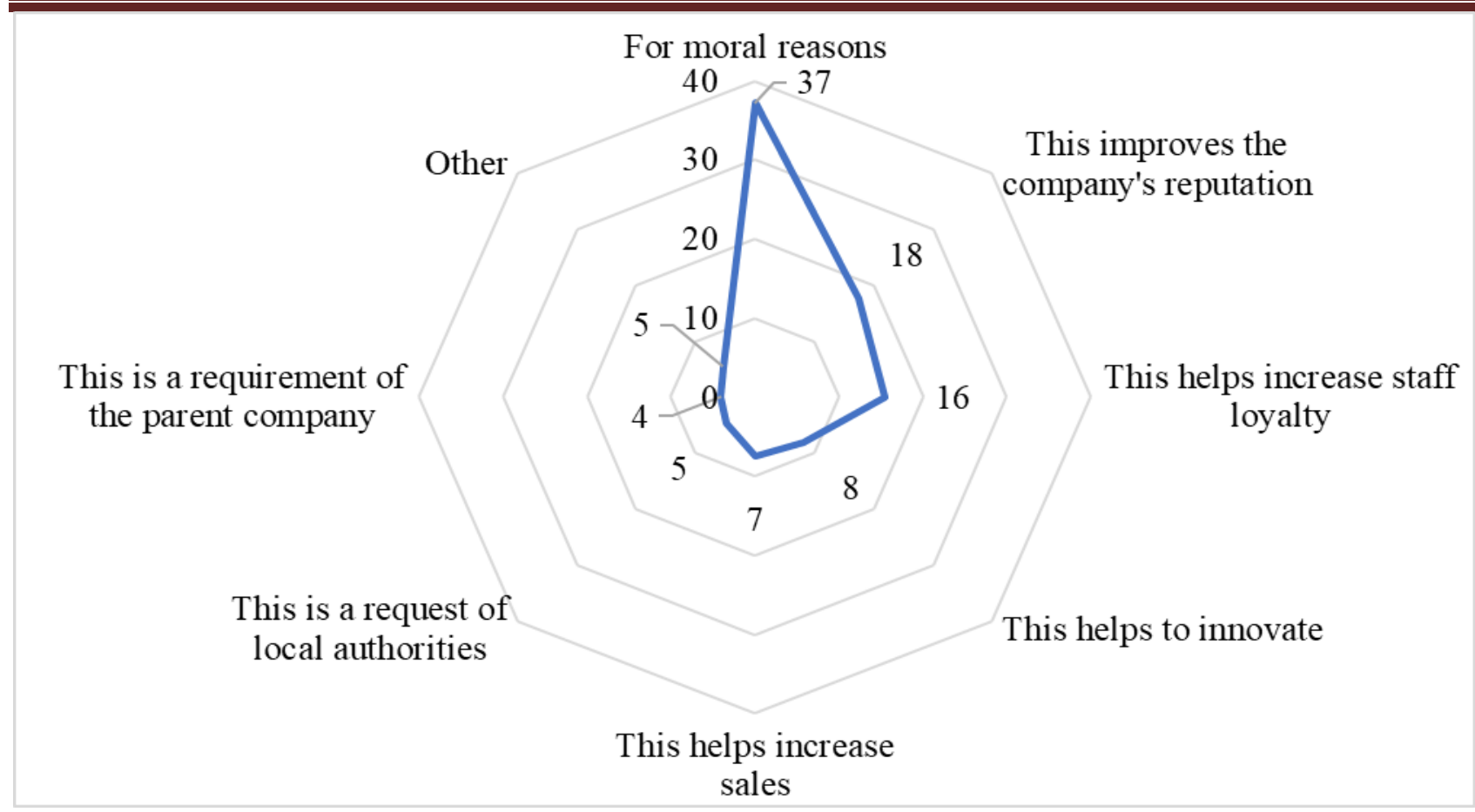

Fig. 3. Distribution of answers to the question "Why does your company carry out socially responsible activities" in $2018, \%$

Sourse: depicted according to the data [24, p. 12-13].

The initiative to implement socially responsible activities of the company in $48 \%$ of cases belongs to the management of companies and in $21 \%$ of cases to its employees (Fig. 4), which indicates a high interest of internal stakeholders in socially responsible activities and disclosure of non-financial information about its activities.

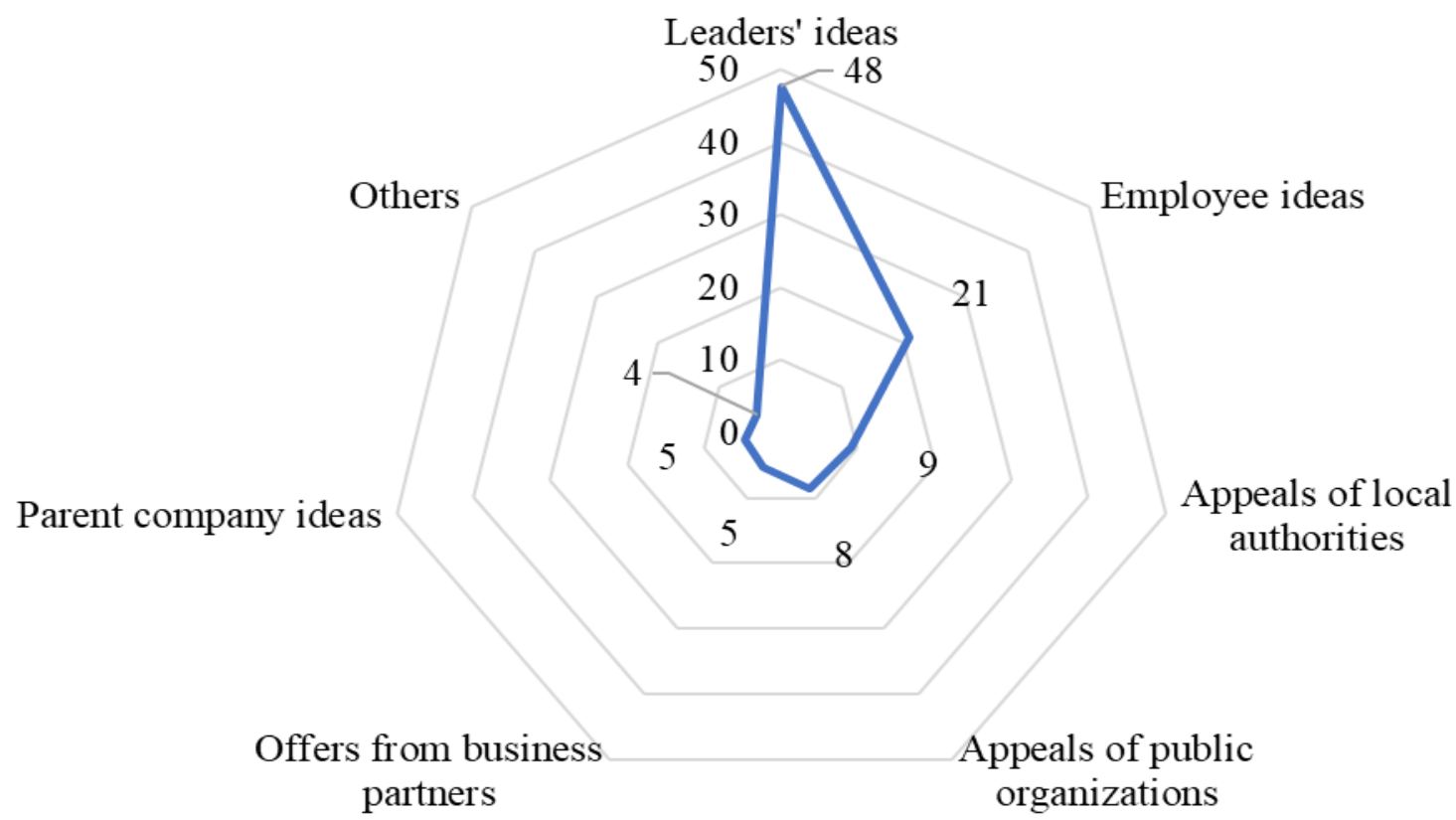

Fig. 4. Distribution of answers to the question "Who or what is the source of ideas for the implementation of socially responsible activities of the company" in $2018, \%$

Sourse: depicted according to the data [24, p. 26-27]. 
At the same time, internal stakeholders consider increased competitiveness and saved resources as the main advantages of implementing socially responsible activities. Obstacles to implementation are low awareness and lack of funds.

There are no uniform requirements for the content of the non-financial report in Ukraine, which leads to the fact that business entities disclose arbitrary information, which, for the most part, positively characterizes their activities.

Thus, during 2016-2017 there were the same trends in the share of issues disclosed in the reports on corporate social responsibility of Ukrainian enterprises, namely the largest share falls on the impact on jobs (staff development, health and safety, the presence of a trade union and collective agreement, corporate volunteering, work-life balance, promotion of women, employee complaints system, etc.) (29\% and $26 \%$ respectively), environmental policy and its results $\left(\mathrm{CO}_{2}\right.$, other emissions, water, environmental audit and its results, fines, environmental certificates, environmental projects of the company) (19\% and $20 \%$ respectively) and community development and support policies (community strategy, business development, education, health) and its results (20\% and $20 \%$, respectively, by year) (Fig. 5).

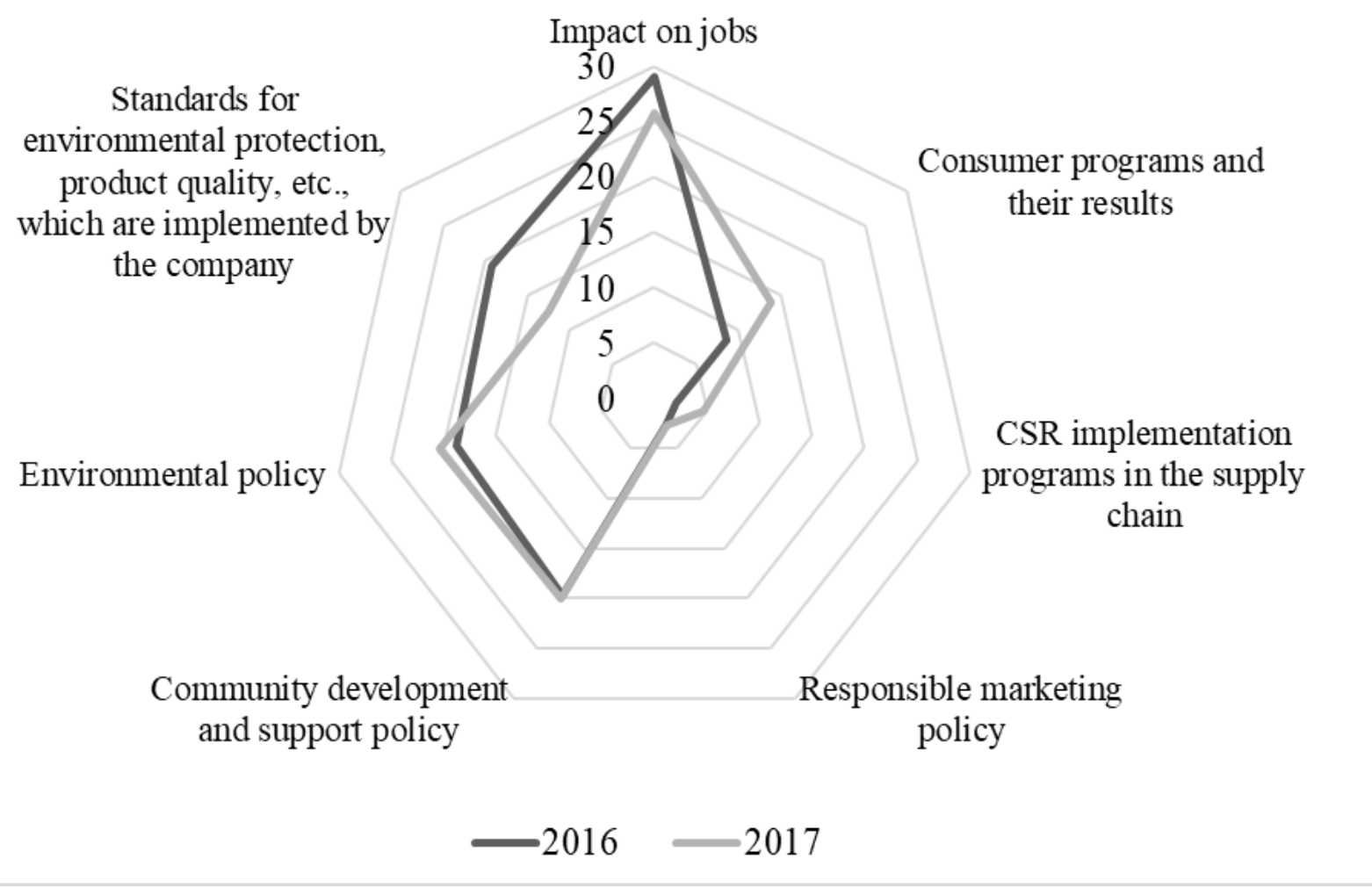

Fig. 5. The share of issues disclosed in the reports on corporate social responsibility of Ukrainian enterprises, \%

Sourse: depicted according to the data [25, p. 20-21].

The share decreased only after the disclosure of information on environmental standards, product quality, etc., implemented by the company (19\% and 13\%, respectively, by year), which is in line with global trends (Fig. 6). 


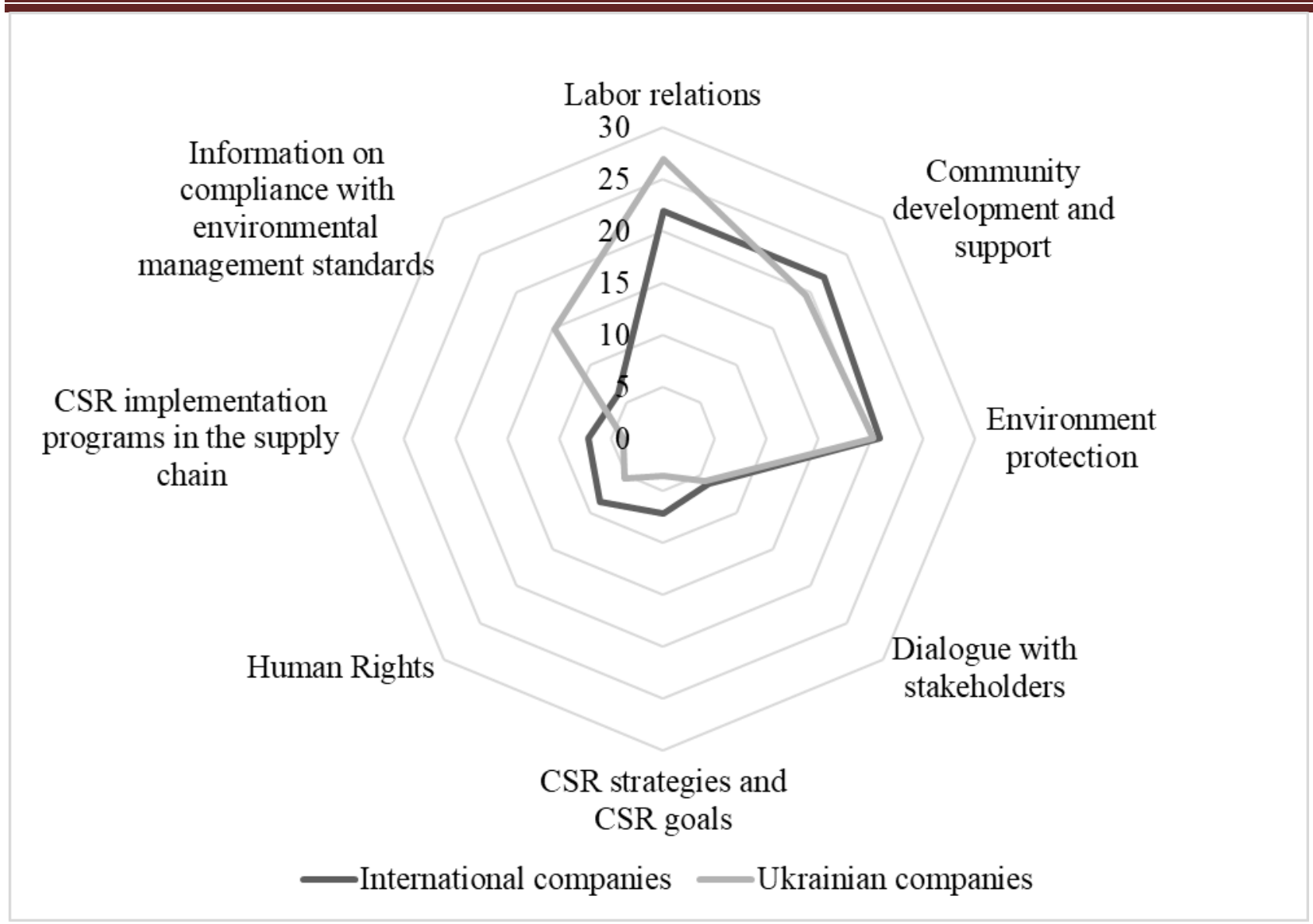

Fig. 6. The share of issues disclosed in the reports on corporate social responsibility of Ukrainian enterprises and international companies for $\mathbf{2 0 1 7 , \%}$

Sourse: depicted according to the data [25, p. 25-26].

The level of information disclosure in the reports on corporate social responsibility of Ukrainian enterprises is lower by all indicators compared to international companies, except for the indicator "Information on compliance with environmental management standards", which exceeds $19 \%$. The identified situation is caused by the initial stage of formation of non-financial reporting by enterprises of Ukraine, which is characterized by the efforts of enterprises to disclose their activities in a more attractive way.

It is interesting to note that both Ukrainian and international companies disclose a small amount of information on the issue of "Stakeholder Dialogue" (16\% and $23 \%$ respectively). This may be one of the reasons for the difficulties that companies face in determining the composition and structure of non-financial statements. After all, without having information about the requests of interested parties, companies will compile reports that will not fully satisfy their users. Therefore, the purpose of non-financial reporting will not be fully achieved.

We believe that the main issues that need to be addressed before the formation of non-financial statements are:

- determining the requirements of interested users of reporting;

- outlining a set of activities of the enterprise, which is subject to disclosure in non-financial reporting, and sources of information about such areas; 


\section{Agricultural and Resource Economics: International Scientific E-Journal}

http://are-journal.com

- the format of submission of indicators in certain areas of activity;

- the process of preparing indicators for disclosure in reporting;

- ways to confirm reporting indicators;

- dissemination of information on the non-financial report.

Researching the requests of interested consumers of information is a priority before the formation of a set of indicators of non-financial reporting. When working with information, the problem of identifying the interested consumer and meeting his needs becomes important. The need for information is manifested through a conscious need for knowledge. The need for information demands satisfaction and is expressed in the information request.

Information needs depend on various objective and subjective factors, which led to their division into:

- subjective (current) information needs, which are determined by the desire of the subject to be aware of a particular area of their interests;

- objective (special) information needs related to the professional activity of the subject and the performance of his official duties.

Users of non-financial reporting of agricultural enterprises are:

1) internal stakeholders - employees, owners, including shareholders;

2) external stakeholders - contractors, consumers, creditors, investors, government agencies, NGOs.

The main areas of use of non-financial reporting information by internal and external stakeholders of agricultural enterprises are as follows:

1) establishing compliance of the enterprise's activities with the legislative requirements of Ukraine and the requirements of international agreements;

2) the formation of the stakeholder's personal opinion on the compliance of the enterprise with the requirements of the concept of sustainable development and on the feasibility, sufficiency, adequacy of its actions to achieve such compliance;

3) comparison of results of activity of structural divisions of the enterprise, and also results of activity of the enterprise as a whole in dynamics.

According to the results of the study (method - questionnaire, the number of respondents is 351 internal stakeholders (all employees of the surveyed enterprises), external - 230 people, namely, the heads of relevant legal entities and heads of departments of such legal entities: financial institutions, contractors, budget institutions, as well as representatives of public authorities and public organizations, individuals - consumers of finished products of the surveyed enterprises, community representatives on the territory of the enterprises (research period - January-March 2020) there were outlined the main information needs (both objective and subjective) of internal and external stakeholders of typical for Ukraine agricultural enterprises of various organizational and legal forms and forms of ownership, namely: TDV "Terezine", PJSC "Obukhivske", SVC "Batkivshchyna", which should be the basis for the formation of their non-financial reporting (Fig. 7, 8). 


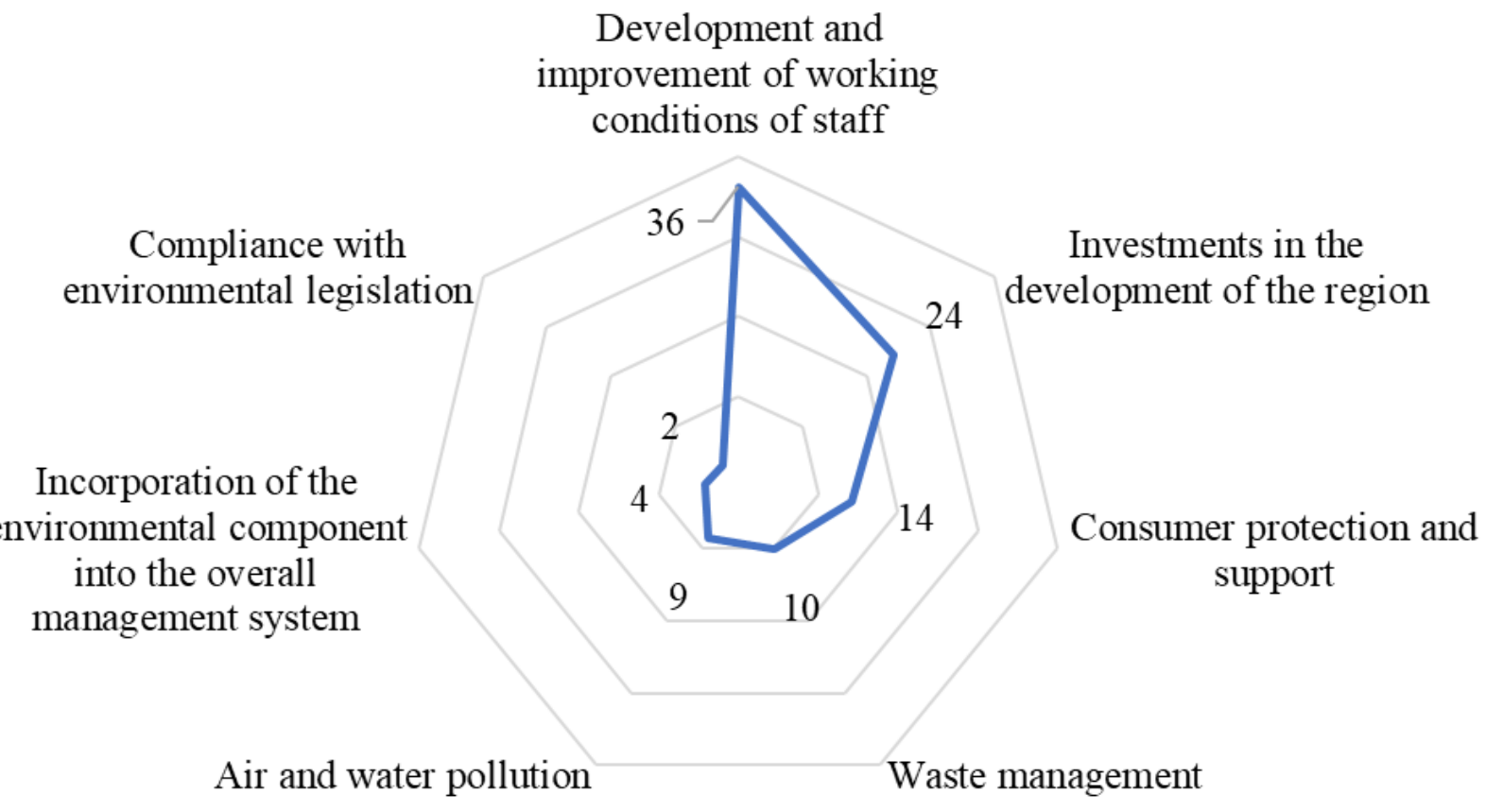

Fig. 7. The share of information needs of internal stakeholders of surveyed enterprises in $2020, \%$

Sourse: developed by the authors.

Actions of the enterprise to achieve the Goals of sustainable development

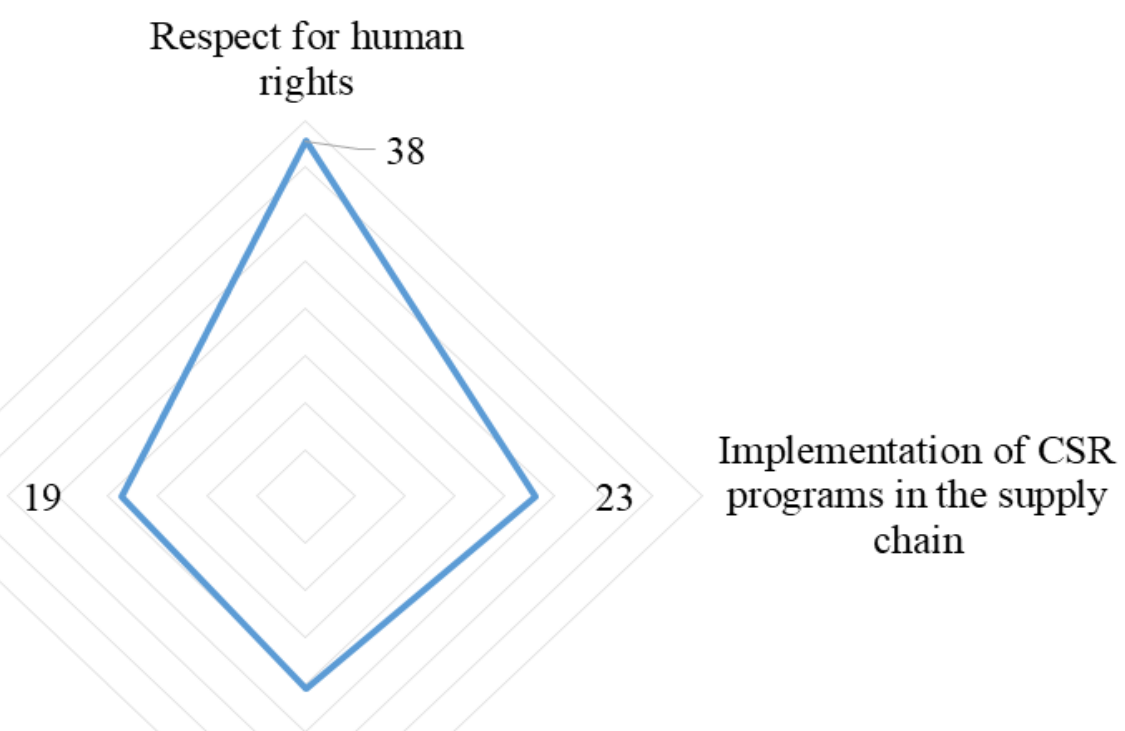

20

Adherence to the policy of executive marketing

Fig. 8. The share of information needs of external stakeholders of surveyed enterprises in $2020, \%$

Sourse: developed by the authors. 


\section{Agricultural and Resource Economics: International Scientific E-Journal}

http://are-journal.com

Thus, in the formation of non-financial reporting TDV "Terezyne", PJSC "Obukhivske", SVC "Batkivshchyna", as well as other agricultural enterprises of Ukraine, should pay special attention to the areas of activity that are of greatest interest to stakeholders. Such areas include those whose share is $19 \%$ or more in the aggregate information needs of internal and external stakeholders.

Thus, the results of the study identified the main activities of the enterprise, which are subject to disclosure in the non-financial statements of agricultural enterprises:

- development and improvement of working conditions of staff,

- investments in the development of the region,

- respect for human rights,

- implementation of CSR programs in the supply chain,

- implementation of responsible marketing policy,

- actions of the company to achieve the Sustainable Development Goals.

When forming information support it is necessary to take into account possible subjectivism and inadequacy of expression of information needs by consumers. The lack of appropriate information potential of the subject leads to the formation of vague and inadequate ideas about the necessary information. Under the same conditions, the needs of different actors may differ in the accuracy and completeness of the information necessary for the successful completion of tasks. Moreover, almost every information need will contain both correct and incorrect ideas about the necessary information, because they depend on the knowledge that the subject has, on his information potential.

The most convenient form of reporting for analysis is standardized in order to ensure comparability of indicators. But at the stage of implementation of nonfinancial reporting in the practice of enterprise reporting, which is currently observed in Ukraine, we consider the arbitrary form of such a report to be optimal.

The main activities of the agricultural enterprise, which are subject to disclosure in non-financial reporting, provide an opportunity to meet the information needs of internal and external stakeholders. Disclosure of such activities will help reduce the cost of users to obtain, process and systematize data, which will reduce inefficient use of resources in the preparation, substantiation, implementation and evaluation of economic decisions.

Identified main areas of activity can be used as a basis for developing a longterm strategy for non-financial reporting of agricultural enterprises, which will simplify the preparation of information for its full disclosure (including infographics, illustrations, photos, which not only proves the reality of initiatives, but visually helps to understand all information). This is due to the fact that the environmental consciousness of society is gradually growing and there is a high probability that in the near future, even potential employees will be interested in non-financial performance of the enterprise. The company's image will only grow if it can inform about such indicators.

Conclusions. Failure to meet information needs of both internal and external 
stakeholders of agricultural enterprises necessitated the definition of the main activities of the agricultural enterprise (including development and improvement of working conditions, investment in regional development, respect for human rights, implementation of CSR programs in the supply chain, implementation of responsible marketing policy, the company's actions to achieve the Sustainable Development Goals), the use of which allows interested parties to obtain data that provide integrated information on the activities of such enterprises. This will not only increase the level of transparency of companies, but also serve as a tool for building their reputation.

Disclosure of information in accordance with the main activities of the agricultural enterprise will reduce the cost of users to obtain, process and systematize data, which will reduce inefficient use of resources in the preparation, substantiation, implementation and evaluation of economic decisions, as well as increase analytical capabilities of its use in the interests of stakeholders. After all, information support must be effective - the income from the use of information must be greater than the cost of its collection and processing. It is very difficult to quantify (determine) the efficiency of information, because the main part of the cost of obtaining information is carried out by its producer, and the results are obtained by both the producer and the consumer. This issue is the line of further research. Modeling the form of nonfinancial reporting for agricultural enterprises, taking into account the identified main areas of activity also presents prospects for further research.

\section{References}

1. Transforming our world: the 2030 Agenda for Sustainable Development, available at: https://www.ua.undp.org/content/ukraine/uk/home/library/sustainabledevelopment-report/the-2030-agenda-for-sustainable-development.html.

2. Zamula, I. and Kireitseva, A. (2013), Environmental liabilities arising from the transactions with atmospheric air as an accounting object. Economics \& Sociology, vol. 6, no. 2, pp. 190-200. https://doi.org/10.14254/2071-789X.2013/6$2 / 17$.

3. Vitale, G., Cupertino, S., Rinaldi, L. and Riccaboni, A. (2019), Integrated management approach towards sustainability: an Egyptian business case study. Sustainability, vol. 11, is. 5, 1244. https://doi.org/10.3390/su11051244.

4. Zamula, I., Tanasiieva, M., Travin, V., Nitsenko, V., Balezentis, T. and Streimikiene, D. (2020), Assessment of the profitability of environmental activities in forestry. Sustainability, vol. 12, is. 7, 2998. https://doi.org/10.3390/su12072998.

5. The Verkhovna Rada of Ukraine (2019), The Law of Ukraine "Basic principles (strategy) of the state ecological policy of Ukraine for the period till 2030", available at: https://zakon.rada.gov.ua/laws/show/2697-19\#Text.

6. Zhuk, V., Bezdushna, Y. and Tyvonchuk, S. (2019), Improvement of IFRS application policy in relation to land assets of agricultural enterprises. Independent journal of management \& production, vol. 10, no. 7, pp. 702-724. https://doi.org/10.14807/ijmp.v10i7.889.

7. Sokil, O., Zhuk, V., Holub, N. and Levchenko, O. (2019), Accounting and 
analytical methods for identifying risks of agricultural enterprises' sustainable development in Modern Development Paths of Agricultural Production. Trends and Innovations, ed. V. Nadykto. Springer, Cham, Switzerland. https://doi.org/10.1007/978-3-030-14918-5_55.

8. Zamula, I. (2015), Accounting component of environmental obligations management in accordance with the principles of sustainable development. Actual problems of the economy, no. 4(166), pp. 261-267.

9. Zamula, I. (2016), Profitability analysis for eco-friendly products within marketing research. Actual problems of the economy, no. 8(179), pp. 317-322.

10. Saprykina, M. (2019), Why business reports on sustainable development, available at: https://www.epravda.com.ua/columns/2019/10/31/653160/.

11. Ukrenergo has published a report on sustainable development in 2018, available at: https://ua.energy/osnovni-podiyi/ukrenergo-opublikuvalo-zvit-zistalogo-rozvytku-za-rezultatamy-2018-roku.

12. GRI Sustainability Reporting, available at: https://bakertilly.ua/news/id40621.

13. Sokil, O., Zhuk, V. and Vasha, L. (2018), Integral assessment of sustainable development of agriculture in Ukraine. Economic Journal-XXI, vol. 170, is. 3-4, pp. 15-21. https://doi.org/10.21003/ea.V170-03.

14. Atağan, G. (2017), Sustainability reporting versus integrated reporting: BIST Sustainability Index in New Trends in Finance and Accounting, ed. D. Procházka. Springer, Cham, Switzerland. https://doi.org/10.1007/978-3-319-49559-0_47.

15. Bednárová, M., Klimko, R. and Rievajová, E. (2019), From environmental reporting to environmental performance. Sustainability, vol. 11, is. 9, 2549. https://doi.org/10.3390/su11092549.

16. Truant, E., Corazza, L. and Scagnelli, S. D. (2017), Sustainability and risk disclosure: an exploratory study on sustainability reports. Sustainability, vol. 9, is. 4, 636. https://doi.org/10.3390/su9040636.

17. Dobre, E., Oana Stanila, G. and Brad, L. (2015), The influence of environmental and social performance on financial performance: evidence from Romania's listed entities. Sustainability, vol. 7, is. 3, pp. 2513-2553. https://doi.org/10.3390/su7032513.

18. Camodeca, R., Almici, A. and Sagliaschi, U. (2018), Sustainability disclosure in integrated reporting: does it matter to investors? A cheap talk approach. Sustainability, vol. 10, is. 12, 4393. https://doi.org/10.3390/su10124393.

19. Abad-Segura, E., Joaquín Cortés-García, F. and Belmonte-Ureña, L. J. (2019), The sustainable approach to corporate social responsibility: a global analysis and future trends. Sustainability, vol. 11, is. 19, 5382. https://doi.org/10.3390/su11195382.

20. Zyznarska-Dworczak, B. (2018), The development perspectives of sustainable management accounting in Central and Eastern European Countries. Sustainability, vol. 10, is. 5, 1445. https://doi.org/10.3390/su10051445.

21. Ukrainska, L. O., Kriukova, O. M. and Korneieva, H. Y. (2014), Estimation 
of an ecological component of the sustanable development and the ecological and economic calculation in Ukraine. Bulletin of the National University "Yaroslav the Wise Law Academy of Ukraine”, vol. 4, is. 19, pp. 92-101.

22. Environmental Performance Index, available at: https://epi.yale.edu/epiresults/2020/country/ukr.

23. UN analytical reference, available at: http://www.un.org.ua/images/documents/4961/UN\%20Policy\%20Paper\%20on\%20L AND\%20REFORM_UKR_FINAL.pdf.

24. Zinchenko, A. and Saprykina, M. (2019), Development of CSR in Ukraine: 2010-2018. Publishing "Yuston", Kyiv, Ukraine.

25. Zinchenko, A., Reznik, N. and Saprykina, M. (2018), Index of transparency of sites of Ukrainian companies - 2017. Publishing "Yuston", Kyiv, Ukraine.

How to cite this article? Як цитувати цю статтю?

Стиль - ДСТУ:

Zhuk V., Zamula I., Liudvenko D., Popko Ye. Development of non-financial reporting of agricultural enterprises of Ukraine. Agricultural and Resource Economics. 2020. Vol. 6. No. 4. Pp. 76-89. URL: https://are-journal.com.

Style - Harvard:

Zhuk, V., Zamula, I., Liudvenko, D. and Popko, Ye. (2020), Development of non-financial reporting of agricultural enterprises of Ukraine. Agricultural and Resource Economics, vol. 6, no. 4, pp. 76-89, available at: https://are-journal.com. 